\title{
A GIS Approach for Rapid Identification of Run-of-River (RoR) Hydropower Potential Site in Watershed: A case study of Bhote Koshi Watershed, Nepal
}

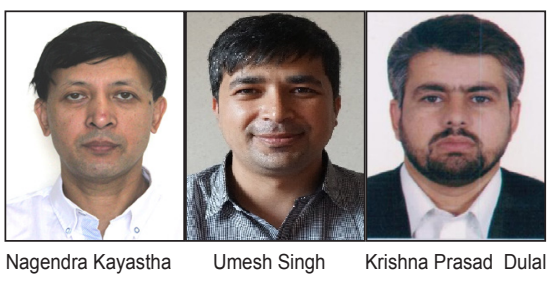

\author{
Nagendra Kayastha, Umesh Singh and Krishna Prasad Dulal
}

\begin{abstract}
A new Geographical Information System (GIS) approach is proposed to assess primary potential hydropower site, explicitly identifying highly possible hydropower locations spatially, over a large area in a short time. The results from this approach were validated with an existing hydropower site in the Bhote Koshi catchment in Nepal. Altogether 885 number of searches made along the river streams each covered a circular area of radius $10 \mathrm{~km}$, with distance between headwork and power houses of $500 \mathrm{~m}$ intervals, thus, identified 297 highly potential sites out of total 2655 during evaluation. The results indicate that, 52 sub-catchments have potential areas and seven specific hydropower locations overlapped with existing hydropower projects. This approach is suitable for initial screening only and the produced results significantly facilitate further in-depth feasibility study to engineering and economic analysis for hydropower potential of the basin.
\end{abstract}

Keywords: GIS approach, Run-of-River, watershed, Bhote Koshi, Nepal

\section{Introduction}

Tydropower is considered as a clean source 1 of renewable energy. Increasing demand for renewable energy has currently increased investments in hydropower globally after several decades of stagnancy. At present, total global hydropower installed capacity is $1,246 \mathrm{GW}$ (IHA, 2017), which comprises of about $68 \%$ of current renewable energy production and $16.6 \%$ of global electricity generation (REN21, 2017). The current global hydropower generation is less than $30 \%$ of the technically feasible global hydropower potential. However, recent studies have shown that around 3,700 major dams for hydropower purpose are under construction or at planned phase, mostly in the developing countries. It would increase the global hydropower electricity generation by $70 \%$ and the development is likely to continue to increase in the future (Zarfl, et al., 2015).

Hydropower holds a great economic importance in Nepal which is generously endowed by nature in water resources. It receives an average rainfall of about 1530 mm over the country (WECS, 2005) and the total runoff per year from the country, including run-off from the Tibetan catchment, is estimated to be about 225 billion cubic meters (WECS, 2011). Topographic elevation varying from 60 masl to 8848 masl, within a short lateral (north-south) extension of 145-248 km, has provided steep topographic gradient for potential hydropower generation. Based on that, an old study reveals that Nepal has a gross hydropower potential of 83,500 MW (Shrestha, 1966). More recent study has estimated runof-river (RoR) gross hydropower potential of 53,836 MW at 40\% dependable flow (Jha, 2010).

Gross hydropower potential is defined as the maximum theoretically possible amount of energy stored in a stream (Arefiev et al., 2015), which in real life application does not occur, because of environmental flows and restrictions, other water uses and economic cost/benefit analysis (Palomino Cuya et al., 2013; Shrestha, 2016). So, the part of the gross hydropower potential which can be developed based on existing site condition, bylaws, present infrastructure and construction technologies and experience in hydropower development is called the technical potential and the part of the technical potential which is economically and financially viable is referred as the economic potential (Arefiev et al. 2015).

Different figures on technical and economical hydropower potential of Nepal have been reported by different authors. Pradhan (2009), referring to Shrestha (1966) and WECS (2009), reports the technical and economical hydropower potential of Nepal as 45,610 MW and 42,133 MW respectively. Those estimation were based on identified 114 and 66 project sites respectively all over the country. Shrestha (2016) himself states the technical potential of Nepal as 43,442 MW or $179,000 \mathrm{GWh} /$ year, which were based on the identified 122 projects. Shrestha also reports different figures of economical potentials as $68,700 \mathrm{GWh} /$ year (ESCAP, 1987) and 12,000 MW (Shrestha, 2015). After the Department of Electricity Development (DoED) of the Government of Nepal started granting licenses for the study and construction of Hydropower projects to the Independent Power Producers (IPPs), in past two decades, several small to medium projects have also been further identified. As of 10th June 2018, DoED reports that projects with total installed capacity of $1006.8 \mathrm{MW}$ are operating, 4689.1 MW have acquired licenses for construction, 4703.3 MW have completed the study, 24130.8 MW are under study and 5661.5 MW have applied for license for the studies. It remains unclear to what extent these figures are incorporated in the earlier assessments. Some may, however, overlap with the 
projects identified for assessment of the technical and economic potential figures.

The technical and economic hydropower potential figures of Nepal reported by different authors have been based on the assessment carried out several decades ago in a different technical and economic scenario with limited data. More recent figures (Shrestha, 2015) are also based rather on preliminary assessments. Over the decades, Nepal has observed development in infrastructure, technology and experience in hydropower development and growth in economy. At the same time much of the topographic and hydrological data and modelling tools have become available since the past estimates. So, it becomes imperative that a systematic study be done, in order to estimate the technical and economical hydropower potential of Nepal in the present context.

A technical and economic potential assessment first requires identification of hydropower schemes in a basin. The schemes can be either RoR or storage scheme. The identified schemes are then screened based on their technical and economic feasibility and, the technical and economic potential of the basin is computed by summing up the technically and economically feasible schemes respectively. Due to steep topography, narrow valleys and concave profile of the rivers, RoR schemes have abundant potential in the streams located at the upper part (and most part) of the catchment and storage potential is limited only to rivers located at the lower parts of the catchment (Shrestha, 2016). The scope of this paper is limited only to the identification of Run-ofRiver (RoR) hydropower schemes in a basin.

New opportunities are arising for evaluation of hydropower potential since the innovative development of remote sensing and satellite data, and their easiness of data processing due to the progress in GIS tools. As such, GIS based application have been widely used to re-estimate hydropower potential in many countries around the world (Alterach et al., 2009; Arefiev et al., 2015; Ballance et al., 2000; Feizizadeh and Haslauer, 2012; Hall et al., 2004; Punys et al., 2011; Ramachandra et al., 2004). Despite having great potential, GIS based technology has been used to lesser extent for the assessment of the techno-economical potential because of the complexities in spotting the RoR hydropower schemes. The run-of-river hydropower projects use the flow, and elevation difference in a stream reach to generate a capacity of power. Although, both increase along the river flow direction a suitable site selection involves trade off with other project variables (e.g. water way length). Determining such project schemes accurately at a river basin scale requires a high degree of effort and advanced programming skills.

Few literatures are available on the use of GIS tool in spotting RoR schemes. Rojanamon et al. (2009) used GIS method to identify small hydropower schemes in Upper Nan River basin in Thailand. Yi et al. (2010) discuss algorithm and criteria to generate automated tool for locating small hydropower scheme and applied the tool to identify hydropower schemes in Bocheong River Basin in Korea. Larentis et al. (2010) extended method proposed by Yi et al. (2010) and developed a Hydrospot tool and validated it in the Taquari-Antas River Basin in Brazil.

This contribution also presents an automated program that locates RoR hydropower schemes - a headwork and its corresponding powerhouse-continuously along the river stream and tributaries network in a river basin. The program is developed in MATLAB and processes the GIS based data to provide attributes of potential headwork and powerhouse sites including spatially referenced geographic locations. The method has been applied in the Bhote Koshi River basin in Nepal and the results are validated with six existing and planned hydropower plants in the basin.

\section{Methodology}

The process of proposed framework is shown in Figure 1. This is classified in four steps: a) selection of input data (extraction of digital elevation model (DEM) for selected basin), b) catchment delineation and stream network generation, c) hydropower scheme (headwork and powerhouse) spotting, and d) extraction of attributes of the hydropower scheme. Q-SWAT, a GIS based software, is used in steps a and $b$ to generate GIS data for river stream and tributaries networks within the selected watershed. The algorithm developed in MATLAB platform is used to execute steps $\mathrm{c}$ and $\mathrm{d}$.

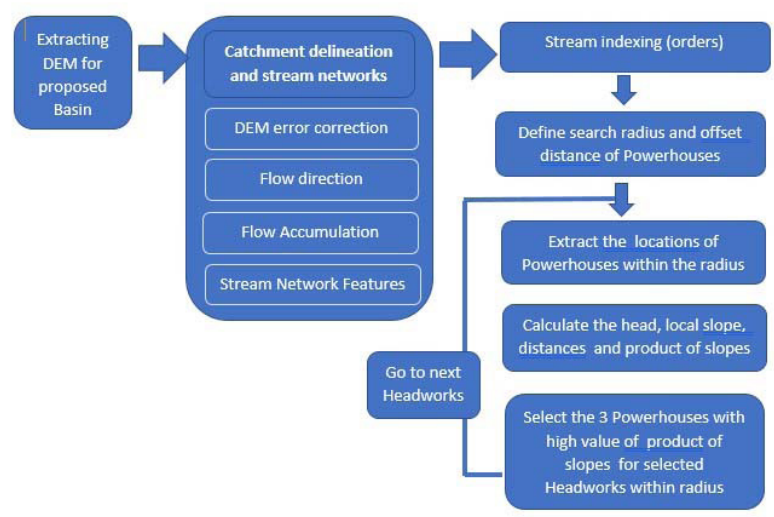

Figure 1. Analytical framework of algorithm

\section{DEM Selection}

The first step is to select spatially covered data sets for selected area. A hydropower potential assessment requires boundaries, topography, geometric information on stream networks, and hydrologic information on watershed. These attributes can be derived from DEM using widely available GIS applications. Thanks to 
the rapidly developing remote sensing data acquiring technology, DEMs are now freely available. SRTM and ASTER-GDEM are available at $30 \mathrm{~m}$ spatial resolutions for entire territory of Nepal. However, ASTER-GDEM is used in this study because of its better vertical accuracy compared to SRTM in Himalayan region (Mukherjee et al., 2012). The global vertical accuracy of ASTER-GDEM version 2 is reported as $17 \mathrm{~m}$ at $95 \%$ confidence interval (Tachikawa et al., 2011).

\section{Catchment delineation}

Catchment delineation is done to create boundary area and drainage networks of watershed, which is usually extracted from DEM by creating boundary that represents contributing the area upstream from a specified outlet point. The corrected DEM, flow direction and flow accumulation rasters are used to develop a vector representation of catchments and drainage lines from selected points in QSWAT. The size and number of sub-basins are defined in catchment depending on study, but it should capture enough spatial variability. In practice, the catchment delineation process is often quite difficult when delineation of headwater streams with valley width is less than DEM resolution. Furthermore, the vertical accuracy of DEMs often causes problems in flat regions and complications in an interpretation of hydrology due to water transfer and changes in underlying geology, which may lead to the delineated watershed, not coinciding with the real watershed.

\section{DEM Errors}

The vertical accuracy of the ASTER-GDEM is affected by the terrain morphology and terrain roughness. The error in elevation is observed to increase in the terrain with topographic elevation greater than $600 \mathrm{~m}$ (Mukherjee et al., 2012), which is common in Himalayan region. Such error stems from uncertainties in data acquisition, spatial resolution and interpolation techniques used for their preprocessing (Purinton and Bookhagen, 2017). Usually, in studies of GIS based hydropower survey, the solution of error refers to removing the artefacts and pits. This solution improves the representation of shapes and elevation grid of streams that are used in watershed for the hydrological analysis.

The quality of DEM and appropriate processing tools are required to obtain adequate results. Only small segments of the cells are overlaying for stream network in a DEM compare to whole watershed. However, this portion is particularly tending errors in elevation grid that turn out in accurate in representation of streams topography (Schwanghart and Scherler, 2014). The elevation grid filled with spurious sinks in DEMs is always prerequisite to carryout hydrological analysis successfully and also for generating meaningful geographical and flow related information.

Filling of sinks remove any imperfections of grid cell in DEM. Each cell of DEM has at least one neighboring cell with equal or lower value of elevation. If cell with higher value surrounds a cell, the water gets trapped in that cell and cannot flow. Sometimes filling large sinks may produce a large flat area that leads to unrealistic gradient in stream networks. In such case, careful choice of approach is required to solve these problems. To eliminate this problem, the modified value of elevation calculated at several neighboring (up and down) segments may need to be averaged for smoothing.

\section{Flow direction and accumulation}

The direction of flow determines the ultimate destination of the water flowing across the surface of the land. Flow direction for a given grid cell is assigned a value to indicate the direction of flow and this value is determined by using the elevation values from the underlying DEM. The water flows from particular grid cell (center) to steepest descent neighboring cells (surrounded) on the underlying topography.

Flow accumulation computes the accumulated numbers of cells that are draining in the flow path pass through grid cell based on flow direction. The values from flow accumulation identify the streams because the flow paths of many points pass through the stream points. Computation of flow accumulations is quite simple once the flow directions are determined. The flow direction would be simple in calculation, once all raster cell of DEM have only one lowering neighbor. However, in presence of flat area in DEM, computations may become complex.

\section{Stream network features}

Each sub-basin contains stream that could be mainstream or tributary and all of these are connected one to another based on flow direction. The flow accumulation gives the number of cells (or area) that drain to a particular cell to define a stream. It is assumed that a stream is formed when a certain area (threshold) drains to a point. This threshold can be defined by using the number of cells in the flow accumulation grid. For example, if we assume an area of $30 \mathrm{~km}$ as the threshold to create a stream, the number of cells corresponding to this threshold area will be 33,333 (30,000,000/ (30 x 30 ). To create stream raster, the corresponding stream cells select raster threshold area of $30 \mathrm{~km}$, which will include cells that have pixel value greater than 33,333 . Streams are linked by assigning a unique number to each link (or segment) in the stream raster. Then creating the stream order for the stream network from flow direction and converting stream raster to a polyline feature.

\section{Stream indexing}

Stream indexing is essential to identify source to mouth direction of stream networks within the watershed. It facilitates to represent longitudinal profile and search descending order for proposed algorithm. 
Each sub-basin contains stream (both end connected with other neighboring streams) or tributary (one end connected with another stream) and all of these are connected one to another. Stream indexing arranges the orders of the stream network by starting at the origin and running down the network, incrementing the order of the polyline feature. The indexing is done by repeating this process for each source.

\section{Search radius and intervals}

The locations of headwork and powerhouse site are placed in equal intervals of $500 \mathrm{~m}$, from upstream end to the downstream end in each perennial stream reach. A search radius is defined to evaluate the numbers of possible powerhouses - which is captured within the circular area for that particular headwork - in downstream (mainstreams or/and tributaries) direction (Figure 2). A search radius of $10 \mathrm{~km}$ is used assuming that the maximum distance between a headwork and powerhouse of an economical hydropower scheme is less than $10 \mathrm{~km}$. Rojanamon et al. (2009) used the value of $5 \mathrm{~km}$ to locate small hydropower schemes. It should be noted that the interval should be always smaller than the search radius. Searching algorithm runs from source of stream to downstream base on indexed stream. The circular area centering the headwork passes down to the adjacent headwork in downstream direction. The search terminates when point is an outlet of watershed. The information extracted from each circular area is then used to estimate the best potential location of powerhouse site.

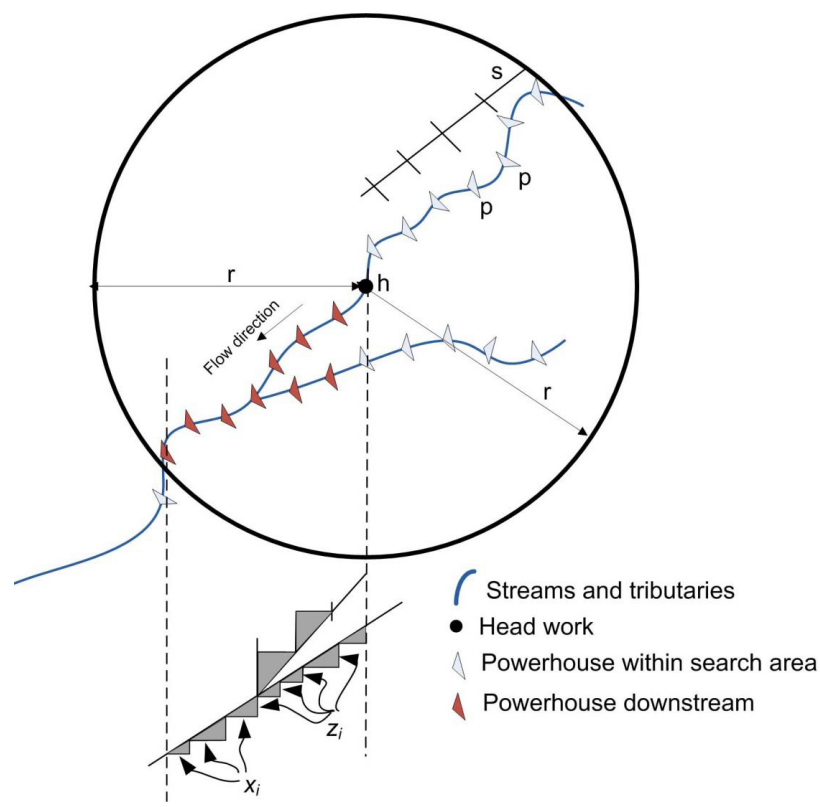

Figure 2. Locations of powerhouses and headwork within search radius

\section{Calculation of head}

Elevation information from DEM data is clipped with stream network to generate topographic profile of streams and tributaries. The vertical distance between headwork and powerhouse is defined as hydraulic head, which is computed for each powerhouse options located in the main stream and tributaries. The local head $\mathrm{H}$ refers to the elevation between each interval (which is a potential headwork and powerhouse site) and cumulatively summed for each powerhouse located in downstream direction and is referred as cumulative head $(\mathrm{CH})$ and is calculated as:

$$
\begin{aligned}
& C H_{i}=\sum_{i}^{1} H_{i} \\
& H_{i}=z_{i}-z_{i-1}
\end{aligned}
$$

Where,

the elevation ( $z$ ) difference between headwork and power house is defined as local head $\mathrm{H}$ of each locations, $\mathrm{CH}$ is cumulative of local head $\mathrm{H}$,

$i$ is number of headwork within the watershed.

While moving from main stream to tributaries, the value of local head is negative and the cumulative head decreases. Thus, the cumulative head is the head used to compute the power potential of the scheme.

\section{Selection of Potential Powerhouse Site}

The Stream Gradient Index (product of slope) is used to detect high potential powerhouse site along river stretch. This value is approximated as the product of local gradient of stream and its cumulative head as follows:

Product of Slope (PS):

$$
P S_{i}=S_{i} * C H_{i}
$$

The value of slope in each interval defined as local slope $\mathrm{S}$,

$$
S_{i}=\frac{z_{i}}{x_{i}}
$$

The arc length $L$ of stream is considered as headrace length that runs along the river and horizontal distance $H L$ is minimum headrace length (Euclidean distance), which also allows the representation of cut-off between headwork and powerhouse. The location of powerhouses within selected circular area is displayed complying with the criteria of location selection. Figure 2 shows one of such headworks.

The possible location of powerhouse and their route line within selected radius of headwork are determined by selecting maximum value of three products of slope and the computation goes on as:

$$
P S_{j}=P S_{\max , i}
$$

Where, PSmax,i is maximum value of (PSj) of different potential powerhouse locations within the 
search circular area, $j$ is number of search or headworks. The idea of setting a maximum PSmax is to avoid locating powerhouse at the highest head which is observed at the farthest point in the search area. Similar criteria is also used by Larentis et al., 2010.

\section{Case Study}

The proposed method was tested in Bhote Koshi basin which is located to Northeast of Kathmandu. Bhote Koshi basin lies in the upstream part of the Sun Koshi river basin and originates from the Tibetan plateau. The total length of the Bhote Koshi River is about $81 \mathrm{~km}$ and the topographic elevation in the basin varies from 600 to 8000 masl. The location of the Bhote Koshi catchment is shown in Figure 3.

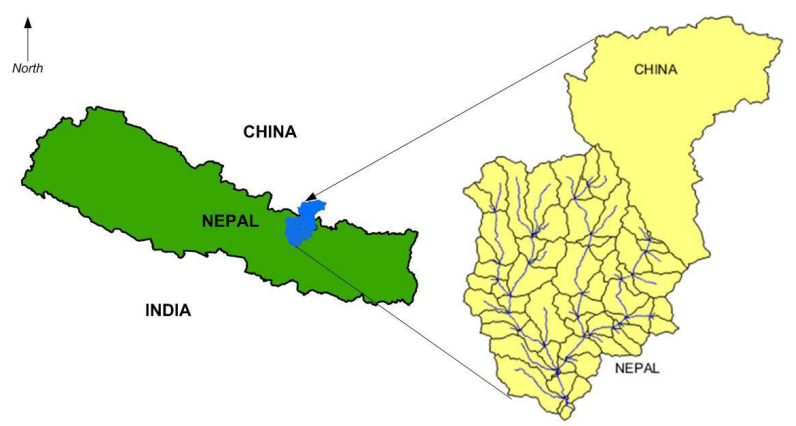

Figure 3. Location of study area in Nepal (left) and Bhote Koshi basin (right)

In order to obtain streams and tributaries, the ASTER Digital Elevation Model (DEM) of $30 \mathrm{~m}$ resolution was processed in QSWAT software. The output of the watershed delineation obtained 63 sub-watersheds and river network with various shapes.

In order to obtain elevation data, DEM data is clipped into stream network to generate stream profile. The river profile was corrected using statistical smoothing analysis shown in Figure 4. Filling or cutting of DEMs with spurious sinks in stream is done to produce hydrologically correct longitudinal profile. The moving average method is employed in an individual stream by correcting cell elevation. The elevation refers to a normal water surface. The elevation data is then extracted at each potential headwork and powerhouse point to calculate the topographic head.

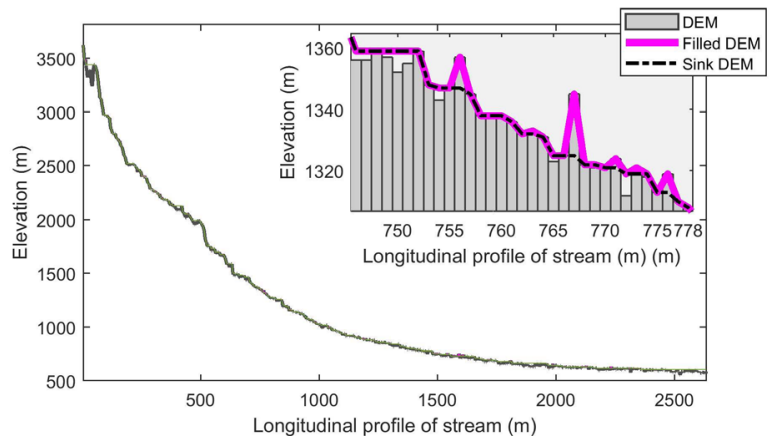

Figure 4. Corrected by filling and cutting of DEM
The streams are indexed in order from source to mount direction and then arranged from upstream to downstream. The search algorithm is then run to select the potential hydropower schemes in the river basin. An interval of $500 \mathrm{~m}$ and the search radius of $10 \mathrm{~km}$ was used.

\section{Results and discussion}

The algorithm searched hydropower schemes for 885 potential headworks located along the river streams considering a circular search area with radius of 10 $\mathrm{km}$ (Figure 5). In each search, several numbers of powerhouses encapsulated within circular area were selected for that particular headwork while only downstream powerhouse - with highest PS value was selected for further analysis. Thus, the screening identified 297 potential powerhouse sites out of 2655 potential powerhouse sites (Figure 6).

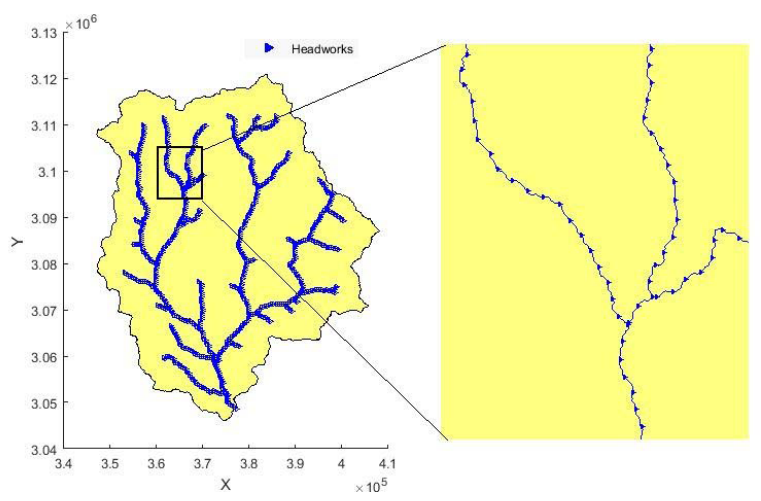

Figure 5. The location of headworks along the stream networks

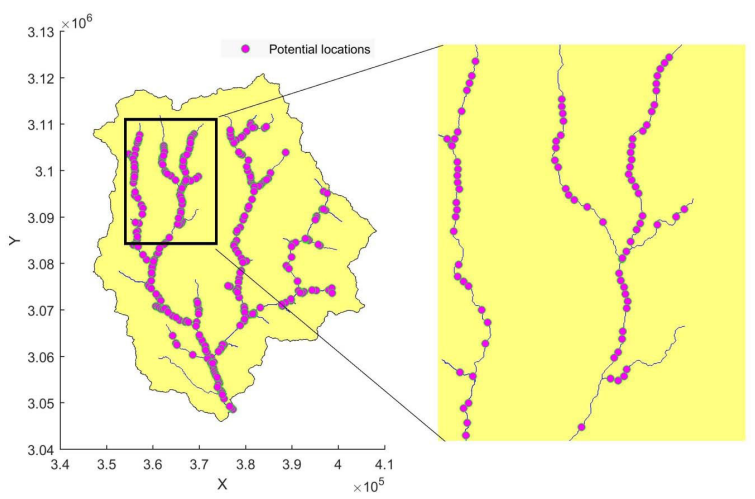

Figure 6 . The location of potential sites along the streams found in this study

The search algorithm was also able to include potential powerhouse sites located in other catchment, which is captured within the circular search area (Figure 7). The identified hydropower schemes were validated against the existing and planned hydropower schemes in the basin. The headworks and powerhouse locations of currently operating and under construction sites are traced from Google Earth. The locations of the headworks and powerhouse of the identified and operating (and under construction) schemes were then compared which is shown in Figure 8. It can be observed that the locations 
of existing schemes are very close to those identified by this study.

The discrepancies in the location occurred because the stream gradient indexes method is a simplified framework for rapid spotting which does not consider other technical factors (e.g. geology). So, this method is suitable for initial spotting only and the produced results should at least be verified in the field by in-depth feasibility study to develop hydropower plant sites.

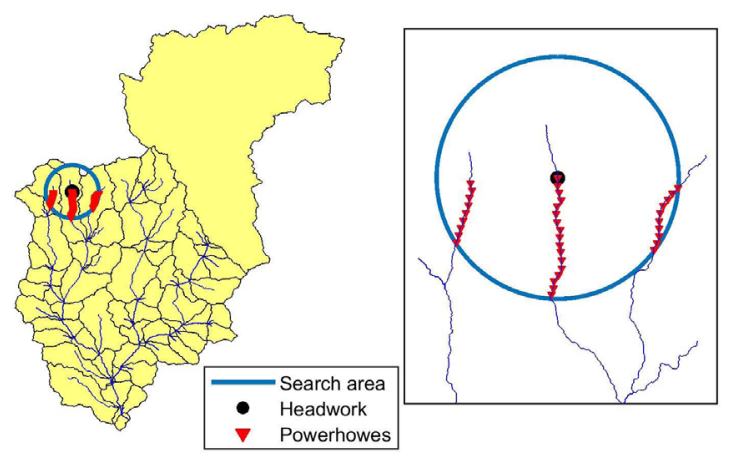

Figure 7. Location of study area in Nepal (left) and Bhote Koshi basin (right)

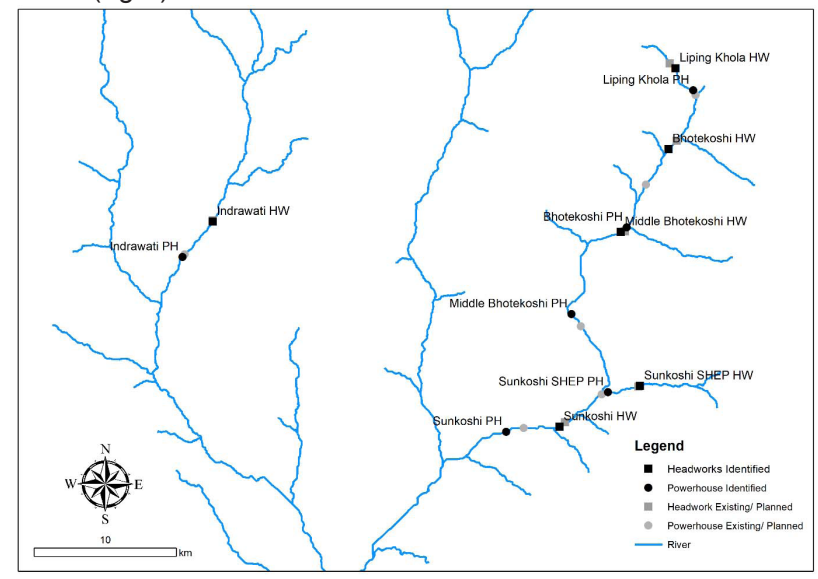

Figure 8. Comparison of the location of potential sites with existing project locations.

\section{Conclusions}

In this study, a GIS based approach is developed to preliminarily analyze hydropower potential sites by using freely available DEM data. An optimization based geospatial approach is introduced followed by several steps, including GIS data processing and hydropower potential site identification based on stream gradient index.

The case study results show that the proposed approach can rapidly identify hydropower schemes in stream reaches for possible future hydropower development. The proposed methodology is targeted at desk study level; consequently, it does not estimate the capacity and cost. However, the result produce by this approach may essentially be used to further determine conclusive economic feasibility for individual site development.
The algorithm used in this study is able to process large volumes of data and terrain of very steep and rugged terrain surface. Therefore, it could be used for feasibility and selection studies for any place of world. It can be further developed as decision making tool for selecting and identifying suitable RoR hydropower project schemes.

\section{Future developments}

Since the outputs from the proposed spotting method is obtained in a spatially distributed form, it can be easily linked with the flow calculated from distributed hydrological model to calculate actual capacity of hydropower. The hydrological analysis is currently being carried out using a SWAT model.

Most of the identified schemes are mutually inclusive. An appropriate scheme should be selected based on economic and environmental criteria. So, a multi criteria decision making tool incorporating technical, environmental and economic factors is being developed. The tool will be used to screen and rank the identified projects.

\section{Acknowledgement}

Part of this study is carried out under the project "Assessment of Hydropower Potential of Nepal", commissioned by the Water and Energy Commission Secretariat (WECS) of the Government of Nepal.

Dr. Nagendra Kayastha obtained his $P h D$ in Hydroinformatics (Hydrology and Water Management) from Delft University of Technology, the Netherlands in 2014 and his Masters degree in Water Science and Engineering with specialization in Hydroinformatics at UNESCO-IHE, the Netherlands in 2007. He has more than 18 years of national and international experiences in river flood and water resource management studies including hydropower and consulting projects in Nepal. Dr. Kayastha has authored over 21 research articles which are published in peer reviewed journals and conference proceedings. He is currently a Visiting Researcher at IHE-Delft institute for water education, the Netherlands and a Visiting Advisor at DK Consult (P.) Ltd. Dr. Kayastha is a founding member of Geomorphological Society of Nepal (GSN), where he also currently holds the position of an Executive Member.

Dr. Umesh Singh obtained his joint Doctoral degree in River Science at University of Trento and Queen Mary University of London in 2015 and his Masters degree in Water Science and Engineering with specialization in Hydraulic Engineering and River Basin Development at UNESCO-IHE, the Netherlands in 2012. Dr. Singh is currently working as a Senior Research Engineer 
at Hydro Lab Pvt. Ltd., where he is responsible for carrying out physical and numerical modelling of headworks of water resource projects. Previously as a Water Resources Research Engineer at DK Consult (P.) Ltd., he was involved in hydropower potential study of Nepal. He was also involved in studies of several hydropower projects in Nepal. Dr. Singh is a founding member of GSN, where he also currently holds the position of a Treasurer.

Dr. Krishna Prasad Dulal obtained his PhD in River Morphology from Hokkaido University, Japan in 2009 and Masters degree in Hydraulic Schemes from Federal Institute of Technology, Switzerland in 2005. Dr. Dulal has worked in the water resources and energy sector for over 15 years in various capacities with different organizations including Butwal Power Company, Chilime Hydropower Company Limited, and Nepal Electricity Authority. He has published several articles in national daily newspapers on water resources and energy related issues in Nepal. Currently he is Managing Director at DK Consult Pvt. Ltd. He was a team leader for the study "Assessment of Hydropower Potential of Nepal" for the government of Nepal. Dr. Dulal has served as Board Director for Nepal Electricity Authority for more than 15 months. He is a founding member of GSN, where he also currently holds the position of a General Secretary.

Corresponding E-mail: ush@hydrolab.org

\section{References}

Alterach, J., Peviani, M., Davitti, A., \& Vergata, M. (2009). Evaluation of the residual potential hydropower production in italy. Hydropower and Dams, 5(June).

Arefiev, N., Badenko, N., Ivanov, T., Kotlyar, S., Nikonova, O., \& Oleshko, V. (2015). Hydropower Potential Estimations and Small Hydropower Plants Siting: Analysis of World Experience. Applied Mechanics and Materials, 725-726, 285292. http://doi.org/10.4028/www.scientific.net/ AMM.725-726.285

Ballance, A., Stephenson, D., Chapman, R., \& Muller, J. (2000). A geographic information systems analysis of hydro power potential in South Africa. Journal of Hydroinformatics, 2, 247-254. Retrieved from http://www.iwaponline.com/jh/002/jhoo20247. htm

ESCAP. (1987). Trans-country Power Exchange and Development.

Feizizadeh, B., \& Haslauer, E. M. (2012). GIS-based procedures of hydropower potential for Tabriz basin, Iran. In GI_Forum 2012: Geovizualisation, Society and Learning (pp. 495-502).

Hall, D. G., Cherry, S. J., Reeves, K. S., Lee, R. D., Carroll, G. R., Sommers, G. L., \& Verdin, K. L. (2004). Water Energy Resources of the United States with Emphasis on Low Head/Low Power Resources.

http://doi.org/10.1016/j.renene.2009.08.003

https:/ / lpdaacaster.cr.usgs.gov/GDEM /
Summary_GDEM2_validation_report_final.pdf IHA. (2017). Hydropower Status Report: International Hydropower Association.

Jha, R. (2010). Total Run-of-River type Hydropower Potential of Nepal. Hydro Nepal: Journal of Water, Energy and Environment, (7), 8-13. http://doi. org/10.3126/hn.v7io.4226

Larentis, D. G., Collischonn, W., Olivera, F., \& Tucci, C. E. M. (2010). Gis-based procedures for hydropower potential spotting. Energy, 35(10), 4237-4243. http://doi.org/10.1016/j.energy.2010.07.014

Mukherjee, S., Joshi, P. K., Mukherjee, S., Ghosh, A., Garg, R. D., \& Mukhopadhyay, A. (2012). Evaluation of vertical accuracy of open source Digital Elevation Model (DEM). International Journal of Applied Earth Observation and Geoinformation, 21(1), 205217. http://doi.org/10.1016/j.jag.2012.09.004

Palomino Cuya, D. G., Brandimarte, L., Popescu, I., Alterach, J., \& Peviani, M. (2013). A GIS-based assessment of maximum potential hydropower production in La Plata basin under global changes. Renewable Energy, 50, 103-114. http://doi. org/10.1016/j.renene.2012.06.019

Pradhan, P. M. S. (2009). Hydropower Development. In D. N. Dhungel \& S. B. Pun (Eds.), The Nepal-India Water Relationship: Challenges (pp. 125151). Dordrecht: Springer Netherlands. http://doi. org/10.1007/978-1-4020-8403-4_5

Punys, P., Dumbrauskas, A., Kvaraciejus, A., \& Vyciene, G. (2011). Tools for Small Hydropower Plant Resource Planning and Development: A Review of Technology and Applications. Energies, 1258-1277. http://doi.org/10.339o/en4091258

Purinton, B., \& Bookhagen, B. (2017). Validation of digital elevation models (DEMs) and comparison of geomorphic metrics on the southern Central Andean Plateau. Earth Surface Dynamics, 5(2), 211-237. http://doi.org/10.5194/esurf-5-211-2017

Ramachandra, T., Jha, R. K., Krishna, S. V., Shruthi, B., . T. V. R., . R. K. J., ... . B. V. S. (2004). Spatial Decision Support System for Assessing Micro, Mini and Small Hydel Potential. Journal of Applied Sciences, 4(4), 596-604. http://doi.org/10.3923/ jas.2004.596.604

REN21. (2016). Renewables 2016 - Global status report. Rojanamon, P., Chaisomphob, T., \& Bureekul, T. (2009). Application of geographical information system to site selection of small run-of-river hydropower project by considering engineering / economic / environmental criteria and social impact. Renewable and Sustainable Energy Reviews, 13, 2336-2348. http://doi.org/10.1016/j.rser.2009.07.003

Schwanghart, W., \& Scherler, D. (2014). Short Communication: TopoToolbox 2 - MATLAB-based software for topographic analysis and modeling in Earth surface sciences. Earth Surface Dynamics, 2(1), 1-7. http://doi.org/10.5194/esurf-2-1-2014

Shrestha, H. M. (1966). Cadastre of Potential Hydropower Resources in Nepal. Moscow Power Institute.

Shrestha, H. M. (2016). Exploitable Potential, Theoretical Potential, Technical Potential, Storage Potential and Impediments to Development of the 
Potential: The Nepalese Perspective. Hydro Nepal: Journal of Water, Energy and Environment, (19), 1-5. http://doi.org/10.3126/hn.v19io.15340

Shrestha, R. B. (2015). Power Sector and Hydropower Development in Nepal. Hydro Nepal: Journal of Water, Energy \& Environment, (16), 18-22. http:// doi.org/10.3126/hn.v16io.12214

Tachikawa, T., Kaku, M., Iwasaki, A., Gesch, D., Oimoen, M., Zhang, Z., \& Carabajal, C. (2011). ASTER Global Digital Elevation Model Version 2 - Summary of Validation Results. NASA Land Processes Distributed Active Archive Center and the Joint Japan-US ASTER Science team. Retrieved from

WECS (2005). National Water Plan, Government of Nepal, Water and Energy Commission Secretariat (WECS), Kathmandu.
WECS. (2011). Water resources of Nepal in the context of climate change: Water and Energy Commission Secretariat (WECS), Kathmandu.

Yi, C. S., Lee, J. H., \& Shim, M. P. (2010). Site location analysis for small hydropower using geo-spatial information system. Renewable Energy, 35(4), 852-861.

Zarfl, C., Lumsdon, A. E., \& Tockner, K. (2015). A global boom in hydropower dam construction. Aquatic Sciences, (77), 161-170. http://doi.org/10.1007/ s00027-014-0377-0 